\title{
PENGARUH KOMPETENSI MENJUAL, KUALITAS HUBUNGAN, DAN PENGALAMAN MENJUAL UNTUK MENINGKATKAN KINERJA TENAGA PENJUALAN (STUDI PADA PT. NEW RATNA MOTOR SEMARANG)
}

\author{
Aulia Arma ${ }^{1}$ \\ Augusty Tae Ferdinand ${ }^{2}$ \\ Susilo Toto Rahardjo ${ }^{3}$ \\ 1,2,3Program Studi Magister Manajemen, Fakultas Ekonomika dan Bisnis \\ Universitas Diponegoro
}

\begin{abstract}
ABSTRAK
Tujuan penelitian ini adalah untuk menganalisis pengaruh kompetensi menjual, kualitas hubungan, dan pengalaman menjual untuk meningkatkan kinerja tenaga penjualan di PT. New Ratna Motor. Adapun objek pada penelitian ini adalah tenaga penjualan PT. New Ratna Motor. Sampel pada penelitian ini sebanyak 139 responden dan teknik pengambilan sampel yang digunakan pada penelitian ini adalah teknik sensus.

Teknik analisis data yang digunakan adalah teknik structural equation model (SEM) dari software AMOS 22. Hasil pengujian menggunakan SEM menunjukan kriteria goodness of fit full model adalah Chi-Square $=92,407$; Probability $=0,000$; $\mathrm{CMIN} / \mathrm{DF}=1,925 ; \mathrm{GFI}=0,893 ; \mathrm{AGFI}=0,826, \mathrm{TLI}=0,960 ; \mathrm{CFI}=0,971$; dan RMSEA $=0,084$. Dengan demikian dapat dikatakan bahwa model dalam penelitian ini layak untuk digunakan.

Hasil penelitian menunjukan bahwa kompetensi menjual berpengaruh positif dan signifikan terhadap kualitas hubungan, pengalaman menjual tidak berpengaruh terhadap kualitas hubungan, pengalaman menjual berpengaruh positif dan signifikan terhadap kompetensi menjual, pengalaman menjual berpengaruh positif dan signifikan terhadap kinerja tenaga penjualan, kompetensi menjual tidak berpengaruh terhadap kinerja tenaga penjualan, kualitas hubungan berpengaruh positif dan signifikan terhadap kinerja tenaga penjualan. Penelitian ini memberikan beberapa keterbatasan penelitian serta agenda penelitian mendatang yang bisa dilakukan pada penelitian selanjutnya.
\end{abstract}

Kata Kunci: Kompetensi Menjual, Kualitas Hubungan, Pengalaman Menjual, dan Kinerja Tenaga Penjualan.

\section{PENDAHULUAN}

Di sebuah perusahaan tenaga penjual merupakan sumber daya manusia yang menyumbang kontribusi untuk mencapai tujuan tersebut. Area krusial pada banyak perusahaan adalah pengaturan tenaga penjual, karena banyaknya orang yang terlibat di dalamnya berdampak pada membengkaknya biaya-biaya yang dikeluarkan (Barker, 1999). Oleh karena itu perusahaan membuat aturan kepada tenaga 
penjualan untuk dapat mencapai target dalam penjualan produk secara berkelanjutan untuk penjualan jangka panjang agar jumlah penjualan dan laba meningkat.

Selanjutnya tujuan yang utama dari adanya tenaga penjualan adalah untuk memperoleh laba, meningkatkan jumlah penjualan agar bisa bertahan untuk kedepan. PT. New Ratna Motor atau yang lebih dikenal dengan nama PT. Nasmoco merupakan perusahaan yang bergerak dibidang otomotif. PT. New Ratna Motor merupakan salah satu dari 5 jaringan utama PT. Toyota Astra Motor yang merupakan Agen Tunggal Pemegang Merek Toyota di Indonesia dalam memasarkan produk Toyota untuk wilayah Jateng \& DIY.

PT. New Ratna Motor telah memiliki 21 cabang atau dealer dengan layanan penjualan unit kendaraan, service dan penyediaan spare part (VSP-Vehicle, Service dan Parts) yang tersebar di hampir seluruh kota-kota besar di wilayah Jawa Tengah dan Daerah Istimewa Yogyakarta (www.nasmoco.co.id). Pada wilayah kota Semarang, PT. New Ratna Motor memiliki lima cabang atau dealer yaitu PT. New Ratna Motor cabang Kaligawe, Pemuda, Majapahit, Gombel dan Siliwangi.

Tabel 1

Data Penjualan PT. New Ratna Motor Semarang Tahun 2011-2015

\begin{tabular}{|c|c|c|}
\hline NO & TAHUN & $\begin{array}{c}\text { TOTAL } \\
\text { PENJUALAN }\end{array}$ \\
\hline 1 & 2011 & 7.010 Unit \\
\hline 2 & 2012 & 8.214 Unit \\
\hline 3 & 2013 & 8.673 Unit \\
\hline 4 & 2014 & 7.895 Unit \\
\hline 5 & 2015 & 7.249 Unit \\
\hline
\end{tabular}

Sumber PT. New Ratna Motor, 2015

Pada Tabel 1.1 dapat diperoleh gambaran bahwa tingkat penjualan mobil PT. New Ratna Motor Semarang mengalami penurunan yang cukup signifikan dari tahun 2014 ke tahun 2015. Penurunan total penjualan yang didukung tidak tercapainya target perusahaan yang menurun mengindikasikan, kinerja tenaga penjual yang tidak optimal.

Berdasarkan fenomena bisnis diketahui bahwa terjadi penurunan penjualan mobil selama periode 2015 di PT. New Ratna Motor Semarang. Karena itu peran tenaga penjual sangat diperlukan untuk mendongkrak angka penjualan mobil. Tenaga Penjualan atau sales dari industri otomotif selalu dituntut agar tidak mudah menyerah untuk meyakinkan pelanggan dan dapat melakukan strategi penjualan yang tepat. Oleh karena itu, untuk meningkatkan kinerja penjualan organisasi maka peran dari tenaga penjual harus mendapat perhatian. Penelitian ini dilakukan untukMenganalisis Kompetensi Menjual yang dimiliki sales berpengaruh terhadap Kualitas Hubungan, Menganalisis Pengalaman Menjual yang dimiliki sales berpengaruh terhadap Kualitas Hubungan, Menganalisis Pengalaman Menjual yang dimiliki sales berpengaruh terhadap Kompetensi Menjual, Menganalisis Pengalaman Menjual yang dimiliki sales berpengaruh terhadap Kinerja Tenaga Penjualan, Menganalisis Kompetensi Menjual yang dimiliki sales berpengaruh terhadap Kinerja Tenaga Penjualan, Menganalisis Kualitas Hubungan yang dimiliki sales berpengaruh terhadap Kinerja Tenaga Penjualan. 


\section{KERANGKA PEMIKIRAN TEORITIS DAN PERUMUSAN HIPOTESIS}

\section{Pengaruh Kompetensi Menjual terhadap Kinerja Tenaga Penjualan}

Tenaga penjualan seharusnya memiliki kemampuan khusus agar berhasil dalam memasarkan produknya untuk mencapai kinerja yang memuaskan serta dituntut untuk mencapai target perusahaan. Penelitian Kohli et al., (1998) menyatakan bahwa sales yang mempunyai kompetensi dan pengalaman maka aktivitas penjualannya sangat efektif.

Studi Schultz, et. al., (2000) meneliti dua karakteristik penting dari tenaga penjualan (pertimbangan konsekuensi masa depan penjualan dan penjualan berorientasi pelanggan) dan pengaruhnya terhadap penggunaan hubungan jangka panjang. Pada gilirannya, hubungan antara orientasi hubungan jangka panjang, dan preferensi untuk kompensasi jangka panjang dieksplorasi.

H1 : Semakin tinggi kompetensi menjual seorang tenaga penjualan, maka semakin baik kualitas hubungan tenaga penjualan dengan konsumen

\section{Pengaruh Pengalaman Menjual terhadap Kualitas Hubungan}

Menurut Kohli, et al., (1998) dalam penelitiannya seorang tenaga penjualan melaksanakan aktivitas penjualan secara rutin, misalnya mengisi daftar kunjungan penjualan secara harian, menyempatkan waktu untuk bertemu dengan pelanggan, selalu tetap berhubungan dengan pelanggan melalui sms, tidak melanggar prosedur perusahaan. Dengan semakin seringnya melakukan aktivitas-aktivitas tersebut maka seorang tenaga penjualan akan bertambah pengalamannya yaitu bisa berupa kegagalan atau keberhasilan dalam penjualan.

Sales yang kurang mempunyai pengalaman akan sabar dalam menghadapi situasi penjualan yang bermacam-macam dalam aktivitas sehari-hari. Sedangkan tenaga penjualan yang berpengalaman umumnya akan sensitif jika dianggap rendah karena prestis mereka, sehingga diharapkan yang berpengalaman akan berusaha lebih keras dibandingkan pada yang tidak berpengalaman dalam mencapai hasil yang telah ditargetkan oleh atasan mereka.

$\mathrm{H} 2$ : Semakin tinggi pengalaman menjual seorang tenaga penjualan, maka semakin baik kualitas hubungan tenaga penjualan dengan konsumen

\section{Pengaruh Pengalaman Menjual terhadap Kompetensi Menjual}

Tenaga penjualan yang berpengalaman diharapkan berkemampuan untuk mengerahkan keterampilan-keterampilan sesuai dengan tugas-tugas penjualan karena memiliki pengetahuan dan pemahaman yang lebih mengenai penjualan. Sehingga apabila dianggap tidak mampu maka tenaga penjualan yang lebih berpengalaman akan merasa tertekan dan malu. Dengan demikian akan meningkatkan orientasi kinerja dan pencapaian pada tujuan-tujuan kinerja mereka.

Menurut Weilbaker (1990) dalam penelitiannya menyatakan bahwa seorang tenaga penjualan yang memiliki pengalaman akan memiliki pengaruh positif akan hasil kinerjanya melalui kemampuan jualnya.

Maka dari itu hipotesis untuk penelitian ini yaitu :

H3 : Semakin tinggi pengalaman menjual seorang tenaga penjualan, maka semakin tinggi kompetensi menjual tenaga penjualan

\section{Pengaruh Pengalaman Menjual terhadap Kinerja Tenaga Penjualan}


Hasil kerja tenaga penjualan diartikan sebagai sebuah cerminan yang merefleksikan keberhasilan atau prestasi seorang tenaga penjualan dalam mengelola sumber daya dan mengkombinasikan dengan aplikasi penerapan strategi-strategi yang secara tepat dan cepat (Agustiana \& Ferdinand, 2004).

Seorang tenaga penjualan yang tingkat kinerjanya tinggi maka mampu menginterprestasikan dan beradaptasi menggunakan strategi penjualan yang memenuhi sasaran kepada apa yang diinginkan pelanggan. Selain itu juga akan lebih memberikan waktu dan memiliki kemampuan untuk bekerja keras dalam hal melayani pelanggan.Verbeke etal.,(2008)dalam penelitiannya menyatakan bahwa sikap dan karakteristik tenaga penjualan yang dimilikinya mempunyai pengaruh yang tinggi dalam penjualan.

H4 : Semakin tinggi pengalaman menjual seorang tenaga penjualan, maka semakin tinggi kinerja tenaga penjualan

\section{Pengaruh Kompetensi Menjual terhadap Kinerja Tenaga Penjualan}

Sujan, et. al., (1994) dalam hasil penelitiannya menyatakan bahwa efek bekerja cerdas dan keras dari kinerja tenaga penjualan sangat berpengaruh dengan ukuran indikator memberikan andil kepada perusaahan melalui kemampuan dalam mencapai pangsa pasar yang dilakukan oleh tenaga penjualan, cepat menjualkan produk baru perusahaan, dan pencapaian target penjualan. Kompetensi yang dimiliki oleh tenaga penjualan dengan efektivitas aktifitas penjualan yang tinggi, s ebagai tolok ukur dari peningkatan kinerja perusahaan yang signifikan serta hal ini merupakan kunci dari kesuksesan kinerja tenaga penjualan pada jangka panjang (Marshall et al, 2001).

Dari hal tersebut dapat disimpulkan keahlian yang dimiliknya akan memberikan sebuah dampak yang bagus bagi perusahaan untuk kedepan, agar perusahaan tetap bertahan dan selalu meraih keuntungan.

H5 : Semakin tinggi kompetensi menjual seorang tenaga penjualan, maka semakin tinggi kinerja tenaga penjualan

\section{Pengaruh Kualitas Hubungan terhadap Kinerja Tenaga Penjualan}

Ketika true relationship terjalin antara penyedia jasa dengan pelanggan, karena sudah adanya hubungan saling percaya antara pelanggan dengan sales, maka pelanggan bisa memaklumi sales apabila mengalami hal yang tidak diinginkan oleh pelanggan dalam hal menjual (Liljander dan Roos, 2002; Matilla, 2001).

H6 : Semakin baik kualitas hubungan seorang tenaga penjualan dengan konsumen, maka semakin tinggi kinerja tenaga penjualan

\section{METODE PENELITIAN}

\section{Teknik Analisis}

Teknik yang dipakai berupa Strukctural Equation Modeling (SEM) dan dioperasikan memakai program AMOS 22. SEM adalah kumpulan dari sebuah teknik statitiskal untuk menguji rangkaian yang hubungannya rumit dengan cara simultan. 


\section{Teknik Pengambilan Sampel}

Teknik sensus adalah pemilihan seluruh anggota populasi yang sudah diketahui sebelumnya, menjadi sampel. Saat ini jumlah tenaga penjualan PT. New Ratna Motor Semarang sebanyak 139 orang. Semua tenaga penjualan ini akan dijadikan responden.

\section{Gambar 2}

\section{Model Penelitian}

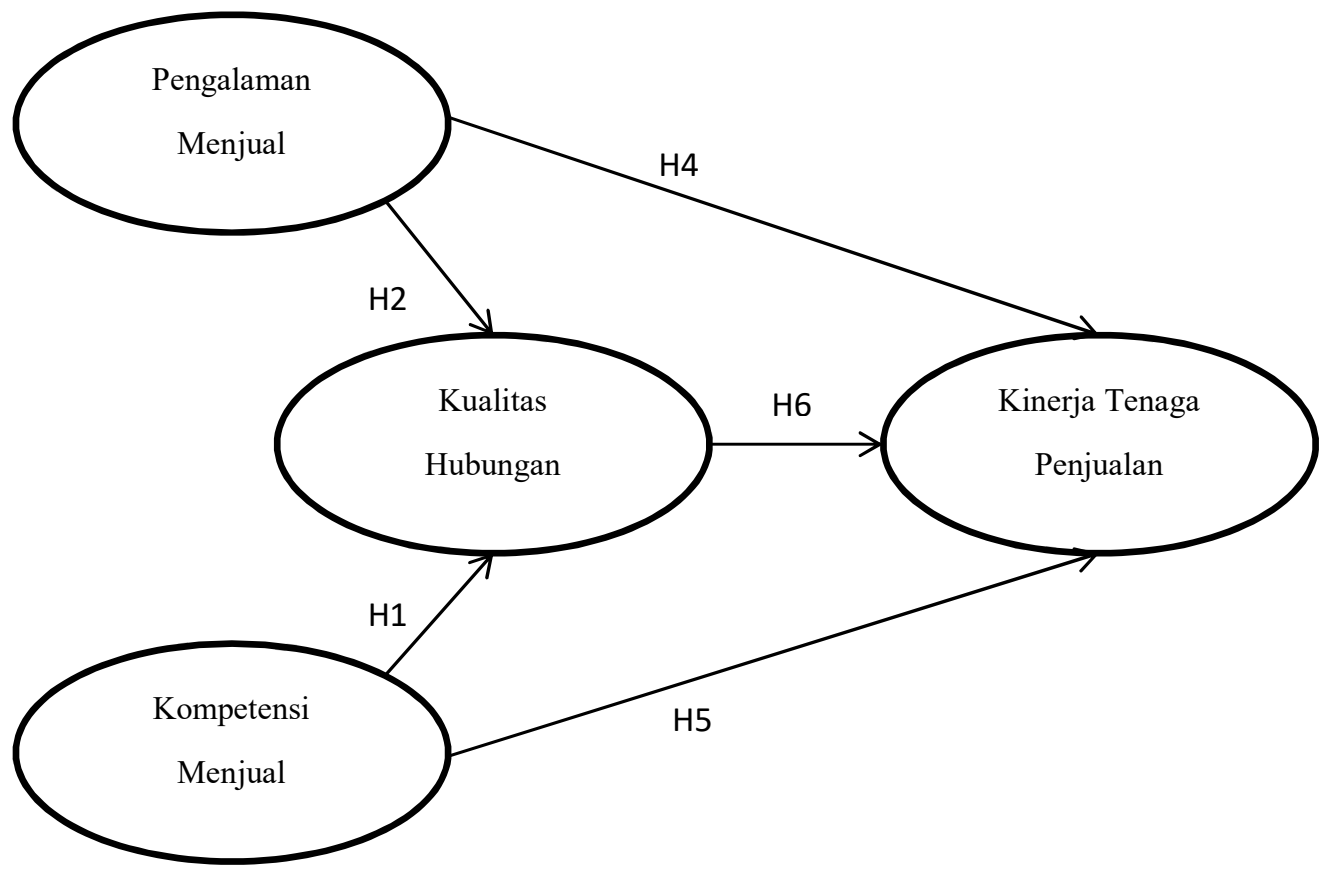

\section{Metode Pengumpulan Data}

Jenis data yang dipakai dalam penelitian adalah data primer. Datanya melalui kuesioner untuk diisi oleh para responden dan berisi mengenai pertanyaanpertanyaan bagaimana kompetensi menjual tenaga penjualan berpengaruh kepada kualitas hubungan dengan konsumen, tingkat pengalaman menjual tenaga penjualan berpengaruh kepada kualitas hubungan dengan konsumen, tingkat pengalaman menjual berpengaruh terhadap kompetensi menjual, pengalaman menjual tenaga penjualan berpengaruh kepada kinerja tenaga penjualan, tingkat kompetensi menjual tenaga penjualan berpengaruh kepada kinerja tenaga penjualan, dan akhirnya kualitas hubungan dengan konsumen berpengaruh kepada kinerja tenaga penjualan. Jadi yang dipakai sumbernya dari jawaban serta pernyataan yang ada di dalam kuesioner tersebut. Sedangkan untuk data sekunder dalam penelitian ini melalui data perusahaan, artikel, dan sebagainya. 
Tabel 3

Definisi Operasional Variabel dan Indikator pada Variabel Kompetensi menjual

\begin{tabular}{|c|c|c|c|}
\hline Variable & $\begin{array}{c}\text { Operational } \\
\text { definition of } \\
\text { Variable }\end{array}$ & $\begin{array}{l}\text { Indicator } \\
\text { Variable }\end{array}$ & $\begin{array}{c}\text { Definition } \\
\text { of the Indicator } \\
\text { Variable }\end{array}$ \\
\hline \multirow{5}{*}{$\begin{array}{l}\text { Kompetensi } \\
\text { Menjual }\end{array}$} & \multirow{5}{*}{$\begin{array}{l}\text { Kompetensi menjual } \\
\text { adalah kemampuan } \\
\text { yang berupa } \\
\text { pengetahuan dan } \\
\text { ketrampilan serta } \\
\text { teknik-teknik yang } \\
\text { dimiliki oleh tenaga } \\
\text { penjualan dalam } \\
\text { proses menjual untuk } \\
\text { memenuhi kebutuhan } \\
\text { yang di inginkan } \\
\text { pelanggan }\end{array}$} & $\begin{array}{l}\text { Pengetahuan } \\
\text { keistimewaan } \\
\text { produk (X1) }\end{array}$ & $\begin{array}{l}\text { Menunjukkan bahwa } \\
\text { tenaga penjualan } \\
\text { harus menguasai } \\
\text { materi-materi tentang } \\
\text { produk yang } \\
\text { akan ditawarkan } \\
\text { kepada konsumen }\end{array}$ \\
\hline & & $\begin{array}{l}\text { Kemampuan } \\
\text { menjabarkan } \\
\text { product } \\
\text { knowledge } \\
\text { yang lengkap } \\
\text { sesuai } \\
\text { kebutuhan } \\
(\mathrm{X} 2)\end{array}$ & $\begin{array}{l}\text { Menunjukkan bahwa } \\
\text { tenaga } \\
\text { penjualan harus bisa } \\
\text { menjabarkan product } \\
\text { knowledge yang } \\
\text { lengkap sesuai } \\
\text { kebutuhan pelanggan }\end{array}$ \\
\hline & & $\begin{array}{l}\text { Kemampuan } \\
\text { beradaptasi } \\
\text { dalam setiap } \\
\text { penjualan } \\
\text { (X3) }\end{array}$ & $\begin{array}{l}\text { Menunjukkan bahwa } \\
\text { tenaga penjualan } \\
\text { harus bisa } \\
\text { menyesuaikan diri di } \\
\text { setiap penjualan yang } \\
\text { berbeda }\end{array}$ \\
\hline & & $\begin{array}{l}\text { Kemampuan } \\
\text { menjual } \\
\text { secara kreatif } \\
\text { mengenai } \\
\text { keunggulan } \\
\text { produk (X4) }\end{array}$ & $\begin{array}{l}\text { Menunjukkan bahwa } \\
\text { selain menguasai } \\
\text { materi keunggulan } \\
\text { produk perusahaan, } \\
\text { seorang tenaga } \\
\text { penjualan juga harus } \\
\text { kreatif dalam menjual }\end{array}$ \\
\hline & & $\begin{array}{l}\text { Kemampuan } \\
\text { dalam } \\
\text { memberikan } \\
\text { solusi atas } \\
\text { pertanyaan } \\
\text { para } \\
\text { pelanggan } \\
(\mathrm{X} 5) \\
\end{array}$ & $\begin{array}{l}\text { Menunjukkan bahwa } \\
\text { tenaga } \\
\text { penjualan harus bisa } \\
\text { memberikan solusi } \\
\text { atas pertanyaan para } \\
\text { pelanggan bukan } \\
\text { hanya sekedar } \\
\text { informasi saja }\end{array}$ \\
\hline $\begin{array}{l}\text { Kualitas } \\
\text { Hubungan }\end{array}$ & $\begin{array}{l}\text { Kualitas Hubungan } \\
\text { adalah memelihara, } \\
\text { dan membangun } \\
\text { relationship dengan } \\
\text { pelanggan pada }\end{array}$ & $\begin{array}{l}\text { Saling } \\
\text { berbagai } \\
\text { informasi } \\
(\mathrm{X} 6)\end{array}$ & $\begin{array}{l}\text { Menunjukkan saling } \\
\text { berbagi informasi } \\
\text { dapat meningkatkan } \\
\text { kualitas hubungan } \\
\text { melalui informasi } \\
\text { tentang produk terbaru, }\end{array}$ \\
\hline
\end{tabular}




\begin{tabular}{|c|c|c|c|}
\hline Variable & $\begin{array}{c}\text { Operational } \\
\text { definition of } \\
\text { Variable }\end{array}$ & $\begin{array}{l}\text { Indicator } \\
\text { Variable }\end{array}$ & $\begin{array}{c}\text { Definition } \\
\text { of the Indicator } \\
\text { Variable }\end{array}$ \\
\hline & \multirow[t]{4}{*}{$\begin{array}{l}\text { sebelum dan sesudah } \\
\text { transaksi }\end{array}$} & & $\begin{array}{l}\text { program untuk } \\
\text { konsumen serta } \\
\text { informasi dari } \\
\text { konsumen mengenai } \\
\text { kerabat yang bisa } \\
\text { dijadikan pelanggan } \\
\text { baru }\end{array}$ \\
\hline & & $\begin{array}{l}\text { Saling } \\
\text { membutuhka } \\
\mathrm{n}(\mathrm{X} 7)\end{array}$ & $\begin{array}{l}\text { Menunjukkan bahwa } \\
\text { saling membutuhkan } \\
\text { sebagai multidimensi } \\
\text { membangun antara } \\
\text { tenaga penjualan } \\
\text { dengan konsumen } \\
\text { mengenai kalkulatif } \\
\text { dan normatif }\end{array}$ \\
\hline & & $\begin{array}{l}\text { Saling } \\
\text { percaya (X8) }\end{array}$ & $\begin{array}{l}\text { Menunjukkan saling } \\
\text { percaya sebagai } \\
\text { fondasi penting dari } \\
\text { pemasaran karena } \\
\text { hubungan adalah } \\
\text { sangat penting dalam } \\
\text { membangun hubungan } \\
\text { kualitas sebagai } \\
\text { individu }\end{array}$ \\
\hline & & $\begin{array}{l}\text { Menjaga } \\
\text { keeratan } \\
\text { hubungan } \\
(\mathrm{X} 9)\end{array}$ & $\begin{array}{l}\text { Menunjukkan menjaga } \\
\text { hubungan yang erat } \\
\text { sebagai hubungan } \\
\text { bisnis untuk jangka } \\
\text { panjang }\end{array}$ \\
\hline $\begin{array}{l}\text { Pengalaman } \\
\text { Menjual }\end{array}$ & $\begin{array}{l}\text { Pengalaman Menjual } \\
\text { adalah pengalaman } \\
\text { yang lebih kompleks } \\
\text { dari seorang tenaga } \\
\text { penjualan yang } \\
\text { didapati pada saat } \\
\text { pertama melakukan } \\
\text { penjualan sampai } \\
\text { dengan saat ini }\end{array}$ & $\begin{array}{l}\text { Berpengalam } \\
\text { an menjual } \\
\text { dalam } \\
\text { beragam } \\
\text { varian produk } \\
(\mathrm{X} 10)\end{array}$ & $\begin{array}{l}\text { Menunjukkan } \\
\text { tenaga penjualan } \\
\text { sering melakukan } \\
\text { aktivitas-aktivitas rutin } \\
\text { penjualan beragam } \\
\text { varian produk, maka } \\
\text { pengalaman menjual } \\
\text { yang dimilikinya, } \\
\text { berupa pengalaman } \\
\text { gagal atau berhasil } \\
\text { dalam melakukan } \\
\text { penjualannya }\end{array}$ \\
\hline
\end{tabular}




\begin{tabular}{|c|c|c|c|}
\hline Variable & $\begin{array}{c}\text { Operational } \\
\text { definition of } \\
\text { Variable }\end{array}$ & $\begin{array}{l}\text { Indicator } \\
\text { Variable }\end{array}$ & $\begin{array}{c}\text { Definition } \\
\text { of the Indicator } \\
\text { Variable }\end{array}$ \\
\hline & & $\begin{array}{l}\text { Berpengalam } \\
\text { an menjual } \\
\text { pada berag } \\
\text { am kelas } \\
\text { pelanggan } \\
(\mathrm{X} 11)\end{array}$ & $\begin{array}{l}\text { Menunjukkan tenaga } \\
\text { penjualan yang } \\
\text { memiliki pengalaman } \\
\text { menjual produk dalam } \\
\text { beragam kelas } \\
\text { konsumen yang terdiri } \\
\text { dari konsumen dengan } \\
\text { status pekerjaan } \\
\text { pegawai negeri, } \\
\text { pegawai swasta dan } \\
\text { wiraswasta }\end{array}$ \\
\hline & & $\begin{array}{l}\text { Berpengalam } \\
\text { an dalam } \\
\text { menghadapi } \\
\text { pesaing (X12) }\end{array}$ & $\begin{array}{l}\text { Menunjukkan tenaga } \\
\text { penjualan yang } \\
\text { memiliki pengalaman } \\
\text { bersaing mendapatkan } \\
\text { strategi dan ide-ide } \\
\text { yang baru untuk } \\
\text { mengahadapi pesaing } \\
\text { dengan percaya diri }\end{array}$ \\
\hline & & $\begin{array}{l}\text { Berpengalam } \\
\text { an dalam } \\
\text { menyesuaika } \\
\mathrm{n} \text { diri dengan } \\
\text { pelanggan } \\
\text { (X13) }\end{array}$ & $\begin{array}{l}\text { Menunjukkan bahwa } \\
\text { tenaga penjualan yang } \\
\text { memiliki pengatahuan } \\
\text { untuk } \\
\text { menemukan hubungan } \\
\text { sebab akibat yang } \\
\text { dirasakan dengan } \\
\text { menggunakan } \\
\text { akumulasi } \\
\text { pengetahuannya }\end{array}$ \\
\hline \multirow[t]{2}{*}{$\begin{array}{l}\text { Kinerja } \\
\text { Tenaga } \\
\text { Penjualan }\end{array}$} & \multirow{2}{*}{$\begin{array}{l}\text { Kinerja tenaga } \\
\text { penjualan adalah } \\
\text { keseluruhan hasil } \\
\text { yang diraih dalam } \\
\text { mencapai tujuan } \\
\text { sesuai dengan target } \\
\text { yang diberikan oleh } \\
\text { perusahaan }\end{array}$} & $\begin{array}{l}\text { Pencapaian } \\
\text { target } \\
\text { penjualan } \\
(\mathrm{X} 14)\end{array}$ & $\begin{array}{l}\text { Menunjukkan tingkat } \\
\text { Pencapaian target } \\
\text { tenaga penjualan } \\
\text { dengan diukur } \\
\text { berdasarkan target } \\
\text { yang diberikan oleh } \\
\text { perusahaan setiap } \\
\text { bulannya }\end{array}$ \\
\hline & & $\begin{array}{l}\text { Volume } \\
\text { penjualan } \\
(\mathrm{X} 15)\end{array}$ & $\begin{array}{l}\text { Menghasilkan volume } \\
\text { penjualan yang } \\
\text { meningkat dengan } \\
\text { patokan unit }\end{array}$ \\
\hline
\end{tabular}




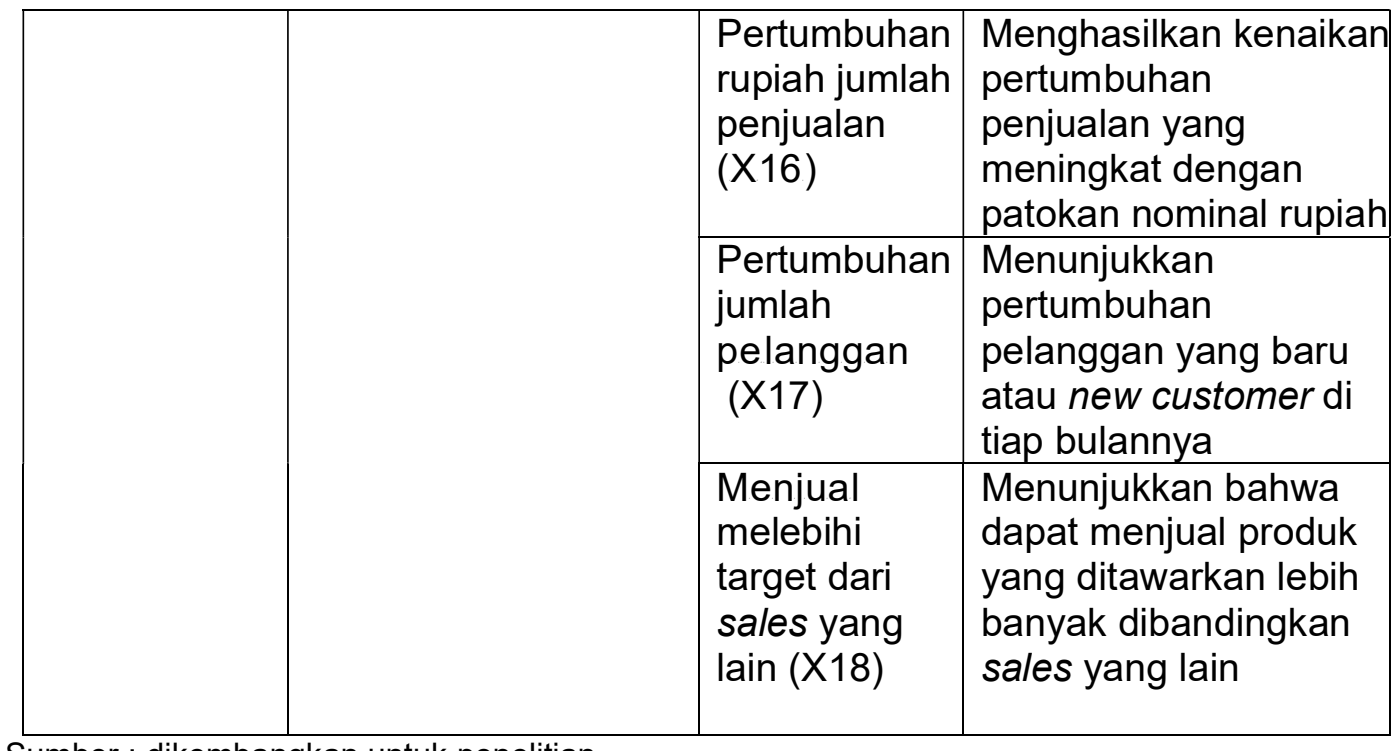

Sumber : dikembangkan untuk penelitian

\section{HASIL PENELITIAN DAN PEMBAHASAN}

\section{Analisis Structural Equation Model}

\section{Gambar 4}

Hasil Uji Structural Equation Model

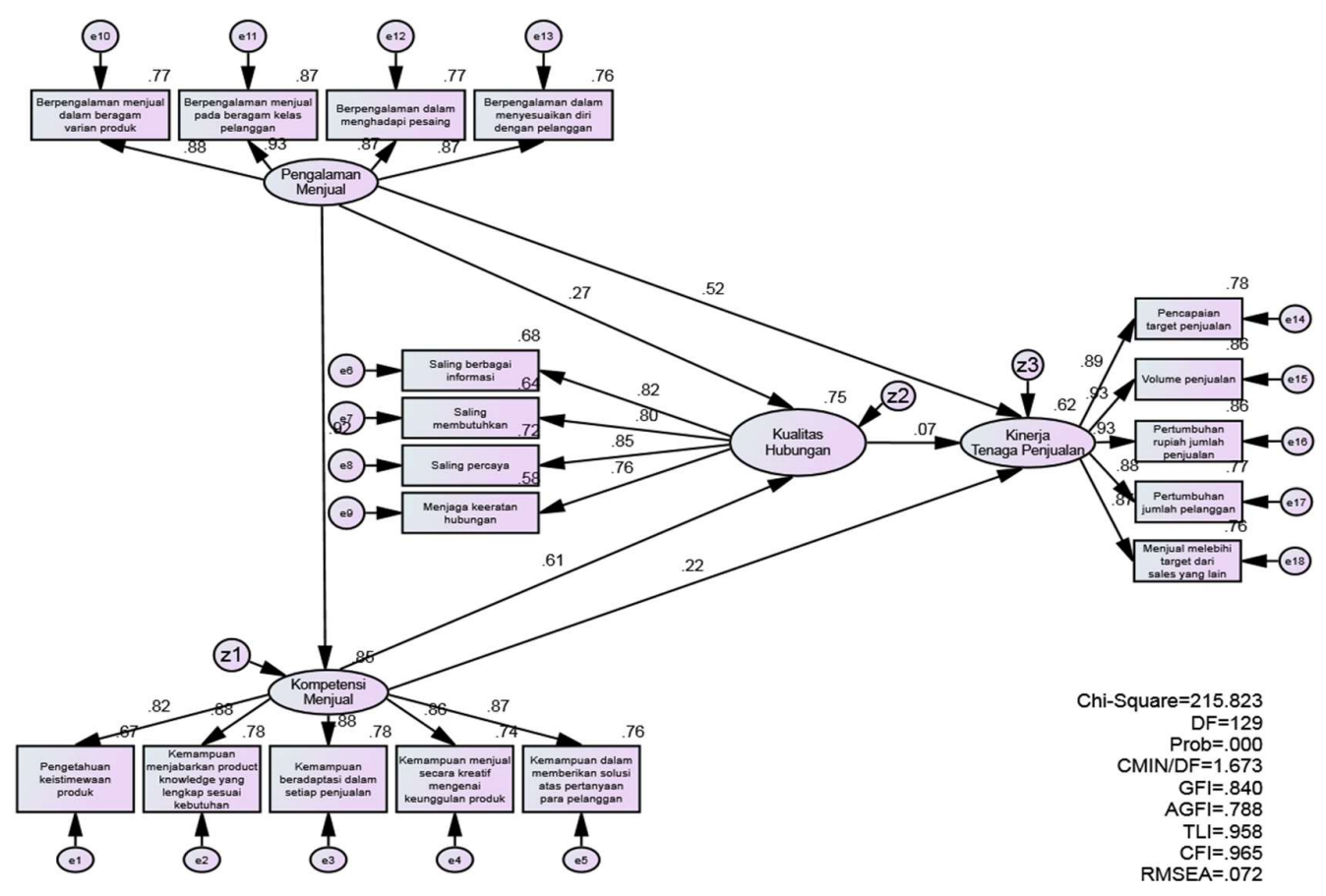


Tabel 4

Hasil Uji Full Model

\begin{tabular}{|l|c|c|l|}
\hline $\begin{array}{c}\text { Goodness of } \\
\text { Fit } \\
\text { Indeks }\end{array}$ & Cut of Value & $\begin{array}{c}\text { Hasil } \\
\text { Analisis }\end{array}$ & \multicolumn{1}{|c|}{$\begin{array}{c}\text { Evaluasi } \\
\text { Model }\end{array}$} \\
\hline Chi-Square & $X^{2}$ dengan df : 129, p :5\% adalah & 215,823 & Marginal \\
\hline Probability & $\geq 0,05$ & 0,000 & Marginal \\
\hline TLI & $\geq 0,90$ & 0,958 & Baik \\
\hline CFI & $\geq 0,90$ & 0,965 & Baik \\
\hline RMSEA & $\leq 0,08$ & 0,072 & Baik \\
\hline CMIN/DF & $\leq 2,00$ & 1,673 & Baik \\
\hline GFI & $\geq 0,90$ & 0,840 & Marginal \\
\hline AGFI & $\geq 0,90$ & 0,788 & Marginal \\
\hline
\end{tabular}

Berdasarkan hasil pengamatan dalam gambar grafik pada analisis full model diatas, disimpulkan bahwa model belum memenuhi kriteria fit secara keseluruhan terutama pada chi-squarenya nilainya masih di atas 156, 508 terpaut cukup jauh dengan 215,823 dan hasil uji hipotesis pada regression weights hanya 3 yang diterima hipotesisnya dari 6 hipotesis.

\section{Modifikasi Model Analisis Structural Equation Model}

\section{Gambar 5}

Structural Equation Model (Phat Diagram) Modifikasi

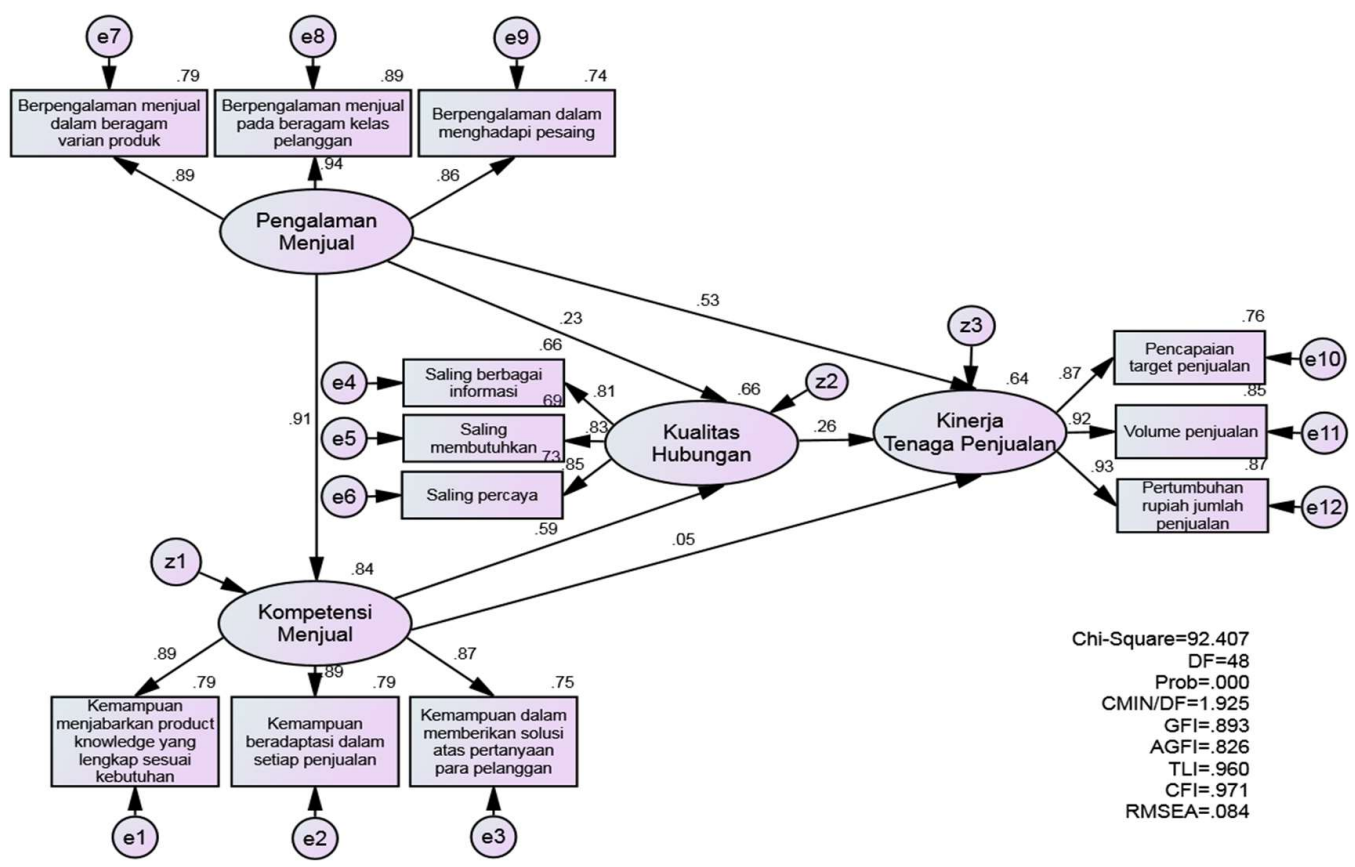


Tabel 5

Hasil Uji Full Model Modifikasi

\begin{tabular}{|l|c|c|l|}
\hline $\begin{array}{c}\text { Goodness of } \\
\text { Fit } \\
\text { Indeks }\end{array}$ & Cut of Value & $\begin{array}{c}\text { Hasil } \\
\text { Analisis }\end{array}$ & $\begin{array}{c}\text { Evaluasi } \\
\text { Model }\end{array}$ \\
\hline Chi-Square & $X 2$ dengan df $: 48, p: 5 \%$ adalah & 92,407 & Marginal \\
\hline Probability & $\geq 0,05$ & 0,000 & Marginal \\
\hline TLI & $\geq 0,90$ & 0,960 & Baik \\
\hline CFI & $\geq 0,90$ & 0,971 & Baik \\
\hline RMSEA & $\leq 0,08$ & 0,084 & Baik \\
\hline CMIN/DF & $\leq 2,00$ & 1,925 & Baik \\
\hline GFI & $\geq 0,90$ & 0,893 & Marginal \\
\hline AGFI & $\geq 0,90$ & 0,826 & Marginal \\
\hline
\end{tabular}

Dalam grafik picture pada full model modifikasi diatas, disimpulkan belum memenuhi kriteria fit modelnya secara keseluruhan akan tetapi untuk jarak nilai ChiSquare dengan tingkat signifikan 5\% tidak terpaut jauh yaitu 65,171 dengan 92,407 tidak seperti pada hasil uji full model sebelum modifikasi yang jaraknya terpaut jauh nilainya dan hasil uji hipotesis pada regression weights menjadi 4 yang diterima hipotesisnya dari 6 hipotesis. Sehingga dengan adanya modifikasi model terdapat perbaikan pada nilai chi-square dan uji hipotesis pada regression weights.

Tabel 6

Regression Weights Structural Equational Model

\begin{tabular}{|c|c|c|c|c|c|c|c|}
\hline & & & Estimate & S.E. & C.R. & $\mathrm{P}$ & Label \\
\hline KM & $<--$ & PM & .915 & .062 & 12.248 & $\star \star \star *$ & par_8 \\
\hline $\mathrm{KH}$ & $<--$ & $\mathrm{KM}$ & .595 & .226 & 2.598 & .009 & par_12 \\
\hline $\mathrm{KH}$ & $<---$ & PM & .235 & .189 & 1.024 & .306 & par_13 \\
\hline KTP & $<--$ & PM & .531 & .207 & 2.558 & .011 & par_9 \\
\hline KTP & $<--$ & $\mathrm{KM}$ & .048 & .271 & .212 & .832 & par_10 \\
\hline KTP & $<--$ & $\mathrm{KH}$ & .264 & .159 & 2.009 & .045 & par_11 \\
\hline
\end{tabular}

Pengujian ini dilakukan untuk menguji keenam hipotesis dalam penelitian ini apakah sudah memenuhi asumsi dari pengujian hipotesis yaitu dengan melihat Critical Ratio $(C R)$ diatas 1,96 serta probabilitas $\leq 0,05$. Berikut kesimpulan hipotesis atas keenam hipotesis penelitian yang digunakan:

H1 : Semakin tinggi kompetensi menjual seorang tenaga penjualan, maka semakin baik kualitas hubungan tenaga penjualan dengan konsumen

Berdasarkan pada hasil penelitian yang didapat dari pengolahan data, menunjukkan bahwa kompetensi menjual berpengaruh terhadap kualitas hubungan. Dengan demikian hipotesis ini diterima dengan berdasarkan pada penelitian terdahulu yang dilakukan oleh Spiro dan Weitz (1990); Kohli (1998); Baldauf, et. al,. (2001); dan Shoemaker dan Johlke (2002).

Kompetensi menjual setelah di modifikasi modelnya dibentuk dari indikatorindikator antara lain kemampuan menjabarkan product knowledge yang lengkap sesuai kebutuhan, kemampuan beradaptasi dalam setiap penjualan, dan kemampuan 
memberikan solusi atas pertanyaan para pelanggan. Sedangkan untuk indikator kualitas hubungan yang sudah di modifikasi antara lain saling berbagi informasi, saling membutuhkan, saling percaya. Indikator-indikator dalam penelitian ini, dipilih berdasarkan pada telaah pustaka, penelitian terdahulu dan dikembangkan oleh peneliti sesuai dengan objek penelitian.

Tabel 7

Hasil Uji Hipotesis

\begin{tabular}{|c|c|c|}
\hline & Hypothesis & $\begin{array}{c}\text { Test Result } \\
\text { (Indeks CR dan P) }\end{array}$ \\
\hline $\mathrm{H} 1$ & $\begin{array}{l}\text { Semakin tinggi kompetensi menjual } \\
\text { seorang tenaga penjualan, maka semakin } \\
\text { baik kualitas hubungan tenaga penjualan } \\
\text { dengan konsumen }\end{array}$ & $\begin{array}{c}\text { Diterima } \\
\mathrm{CR}: 2,598 \text { dan } \mathrm{P}: \\
0,009\end{array}$ \\
\hline $\mathrm{H} 2$ & $\begin{array}{l}\text { Semakin tinggi pengalaman menjual } \\
\text { seorang tenaga penjualan, maka semakin } \\
\text { baik kualitas hubungan tenaga penjualan } \\
\text { dengan konsumen }\end{array}$ & $\begin{array}{c}\text { Ditolak } \\
\text { CR : 1,024 dan } P \text { : } \\
0,306\end{array}$ \\
\hline H3 & $\begin{array}{l}\text { Semakin tinggi pengalaman menjual } \\
\text { seorang tenaga penjualan, maka semakin } \\
\text { tinggi kompetensi menjual tenaga } \\
\text { penjualan }\end{array}$ & $\begin{array}{c}\text { Diterima } \\
\text { CR : } 12,248 \text { dan } P \text { : } \\
0,000\end{array}$ \\
\hline $\mathrm{H} 4$ & $\begin{array}{l}\text { Semakin tinggi pengalaman menjual } \\
\text { seorang tenaga penjualan, maka semakin } \\
\text { tinggi kinerja tenaga penjualan }\end{array}$ & $\begin{array}{c}\text { Diterima } \\
\mathrm{CR}: 2,558 \text { dan } \mathrm{P}: \\
0,011\end{array}$ \\
\hline H5 & $\begin{array}{l}\text { Semakin tinggi kompetensi menjual } \\
\text { seorang tenaga penjualan, maka semakin } \\
\text { tinggi kinerja tenaga penjualan }\end{array}$ & $\begin{array}{c}\text { Ditolak } \\
\text { CR : } 0,212 \text { dan } P: \\
0,832\end{array}$ \\
\hline H6 & $\begin{array}{l}\text { Semakin baik kualitas hubungan seorang } \\
\text { tenaga penjualan dengan konsumen, maka } \\
\text { semakin tinggi kinerja tenaga penjualan }\end{array}$ & $\begin{array}{c}\text { Diterima } \\
\mathrm{CR}: \text { 2,009 dan } \mathrm{P}: 0 \\
045\end{array}$ \\
\hline
\end{tabular}

H2 : Semakin tinggi pengalaman menjual seorang tenaga penjualan, maka semakin baik kualitas hubungan tenaga penjualan dengan konsumen

Berdasarkan pada hasil penelitian yang didapat dari pengolahan data, menunjukkan bahwa pengalaman menjual tidak berpengaruh terhadap kualitas hubungan. Dengan demikian hipotesis ini ditolak. Hal ini tidak sesuai dengan pendapat pada penelitian yang dilakukan Crosby, et. al., (1990).

Pengalaman menjual setelah di modifikasi modelnya dibentuk dari indikatorindikator antara lain berpengalaman menjual dalam beragam varian produk, berpengalaman menjual pada beragam kelas pelanggan dan berpengalaman dalam menghadapi pesaing. Sedangkan untuk indikator kualitas hubungan yang sudah di modifikasi antara lain saling berbagi informasi, saling membutuhkan, saling percaya. Indikator-indikator dalam penelitian ini, dipilih berdasarkan telaah pustaka, penelitian terdahulu serta dikembangkan oleh peneliti berdasarkan pada objek penelitian. 
H3 : Semakin tinggi pengalaman menjual seorang tenaga penjualan, maka semakin tinggi kompetensi menjual tenaga penjualan

Berdasarkan pada hasil penelitian yang didapat dari pengolahan data, menunjukkan bahwa pengalaman menjual berpengaruh terhadap kompetensi menjual. Dengan demikian hipotesis ini diterima. Hal ini sesuai dengan pendapat pada penelitian penelitian terdahulu yang dilakukan oleh Kohli (1998); Baldauf, et,al., (2001); Shoemaker dan Johlke, (2002), dan Weilbaker (1990).

Pengalaman menjual setelah di modifikasi modelnya dibentuk dari indikatorindikator antara lain berpengalaman menjual dalam beragam varian produk, berpengalaman menjual pada beragam kelas pelanggan dan berpengalaman dalam menghadapi pesaing. Sedangkan untuk indikator kompetensi menjual setelah di modifikasi modelnya antara lain kemampuan menjabarkan product knowledge yang lengkap sesuai kebutuhan, kemampuan beradaptasi dalam setiap penjualan, dan kemampuan memberikan solusi atas pertanyaan para pelanggan.

\section{H4 : Semakin tinggi pengalaman menjual seorang tenaga penjualan, maka semakin tinggi kinerja tenaga penjualan}

Berdasarkan pada hasil penelitian yang didapat dari pengolahan data, menunjukkan bahwa pengalaman menjual berpengaruh terhadap kinerja tenaga penjualan. Dengan demikian hipotesis ini diterima. Hal ini sesuai dengan pendapat pada penelitian terdahulu yang dilakukan Kohli, et.al., (1998).

Pengalaman menjual setelah di modifikasi modelnya dibentuk dari indikatorindikator antara lain berpengalaman menjual dalam beragam varian produk, berpengalaman menjual pada beragam kelas pelanggan dan berpengalaman dalam menghadapi pesaing. Sedangkan untuk indikator kinerja tenaga penjualan setelah di modifikasi modelnya antara lain pencapaian target penjualan, volume penjualan dan pertumbuhan rupiah jumlah penjualan.

\section{H5 : Semakin tinggi kompetensi menjual seorang tenaga penjualan, maka semakin tinggi kinerja tenaga penjualan}

Berdasarkan pada hasil penelitian yang didapat dari pengolahan data, menunjukkan bahwa kompetensi menjual tidak berpengaruh terhadap kinerja tenaga penjualan. Dengan demikian hipotesis ini ditolak. Hal ini tidak sesuai dengan pendapat penelitian terdahulu yang dilakukan Crosby, et. al.,(1990) tetapi sesuai dengan penelitian yang dilakukan oleh Ahmad S.Z, et. al., (2010).

Kompetensi menjual setelah di modifikasi modelnya dibentuk dari indikatorindikator antara lain kemampuan menjabarkan product knowledge yang lengkap sesuai kebutuhan, kemampuan beradaptasi dalam setiap penjualan, dan kemampuan memberikan solusi atas pertanyaan para pelanggan. Sedangkan untuk indikator kinerja tenaga penjualan setelah di modifikasi modelnya antara lain pencapaian target penjualan, volume penjualan dan pertumbuhan rupiah jumlah penjualan.

\section{H6 : Semakin baik kualitas hubungan seorang tenaga penjualan dengan konsumen, maka semakin tinggi kinerja tenaga penjualan}

Berdasarkan pada hasil penelitian yang didapat dari pengolahan data, terdapat pengaruh kualitas hubungan dengan kinerja tenaga penjualan. Dengan demikian hipotesis ini diterima. Hal ini sesuai dengan pendapat terdahulu oleh penelitian Cannon \& Homburg (2001).

Kualitas hubungan setelah di modifikasi modelnya dibentuk dari indikatorindikator antara lain saling berbagi informasi, saling membutuhkan, saling percaya. 
Sedangkan untuk indikator kinerja tenaga penjualan setelah di modifikasi modelnya antara lain pencapaian target penjualan, volume penjualan dan pertumbuhan rupiah jumlah penjualan.

\section{KESIMPULAN}

Dari hasil penelitian yang dilakukan, agar kinerja tenaga penjualannya dapat meningkat dapat dilakukan dengan melalui proses kompetensi menjual, kualitas hubungan dan pengalaman menjual mempunyai pengaruh yang berbeda, dimana pengalaman menjual terhadap kualitas hubungan dan kompetensi menjual terhadap kinerja tenaga penjualan mempengaruhi secara negatif, hal ini dikarenakan seorang sales atau tenaga penjualan yang mempunyai kompetensi menjual belum tentu pintar dalam hal menjual dikarenakan menjual itu juga butuh seni atau disebut dengan art of selling oleh sebab itu apabila hanya pintar di teori saja, dalam hal praktek kerjanya belum tentu berhasil menjual sedangkan untuk pengalaman menjual belum tentu bagus juga di dalam membina hubungan dengan pelanggan dikarenakan kadang ada sales atau tenaga penjualan yang hanya melayani karena butuh saja sehingga setelah selesai melakukan pembelian mobil, pelanggan tersebut tidak pernah di follow up lagi seperti menghubungi mereka untuk menanyakan pengalaman dalam memakai atau menggunakan jasa dan produk tersebut, mendengarkan baik-baik keluhan pelanggan dan segera mengatasi dengan memberikan solusi yang dapat memuaskan kedua belah pihak, dari sikap tersebut bahwa sales atau tenaga penjual yang berpengalaman tidak semuanya bagus dalam membina hubungan berbeda dengan sales yang kurang berpengalaman pasti tetap akan mengutamakan hubungan karena membina hubungan dengan pelanggan itu penting sebagai cara agar dapat mencapai target penjualan dari atasan.

Hasil yang berbeda ditunjukkan pada pengalaman menjual terhadap kompetensi menjual, kompetensi menjual terhadap kualitas hubungan, pengalaman menjual terhadap kinerja tenaga penjualan dan kualitas hubungan terhadap kinerja tenaga penjualan dimana hasil yang didapat adalah positif. Untuk variabel yang berpengaruh secara langsung terhadap kinerja tenaga penjualan adalah variabel pengalaman menjual dan kualitas hubungan sedangkan untuk variabel yang berpengaruh secara tidak langsung yaitu kompetensi menjual harus melalui kualitas hubungan untuk mempengaruhi kinerja tenaga penjualannya. Berdasarkan pada uraian diatas dapat diambil kesimpulan bahwa pengalaman menjual dan kualitas hubungan dapat meningkatkan kinerja tenaga penjualan.

\section{Agenda Penelitian Mendatang}

Berdasarkan pada keterbatasan penelitian yang telah didiskripsikan di atas, maka penelitian studi ini masih dapat dikembangkan lebih lanjut pada penelitian yang akan datang mengenai kinerja tenaga penjualan. Misalnya dengan menambahkan beberapa variabel dan indikator yang tidak terdapat pada penelitian ini, untuk dapat dimasukkan dalam penelitian selanjutnya, sehingga hasil dari penelitian tersebut bisa lebih valid. Hasil pada penelitian ini terdapat hasil yang negatif dan tidak signifikan, yaitu pada hipotesis 2 dan 5 sehingga perlu dilakukan perbaikan pada model. harapkan pada penelitian yang akan datang hendaknya dilakukan pada objek penelitian yang lebih luas, misalnya meneliti kinerja tenaga penjualan PT. New Ratna Motor diluar kota Semarang atau seluruh Jawa Tengah dan DIY, sehingga akan dapat mengamati perbedaan faktor-faktor yang mempengaruhi kinerja tenaga penjualan. 


\section{DAFTAR REFERENSI}

Agustina Asatuan dan Augusty Ferdinand, (2004),"Studi mengenai Orientasi Pengelolaan Tenaga Penjualan", Jurnal Sains Pemasaran Indonesia, Vol. III, Nomer 1, p.1-22.

Ahmad S.Z., Basir M. Sah and Kitchen P.J (2010)," The Relationship between Sales Skill and Salesperson Performance, and The Impact of Organization Commitment as a Moderator : An Empirical Study in Malaysian Telecomunication Company", Journal of economics and Management, Vol. 4. No. 2, pp 181-211.

Baldauf, Artur, Cravens, David W; Piercy, Nigel F, (2001), "Examining Business Strategy, Sales Management, and Salesperson Antecedent of Sales Organization Effectiveness", The Journal of Personal Selling and Salles Management, p. 109.

Barker, Tansu A, (1999), "Benchmark of Successful Salesforce Performance", Canadian Journal of Administrative Science, Vol. 16, No. 2, p.95-104.

Crosby, L.A., Evans, K.R. and Cowles, D. (1990), "Relationship quality in services selling: an interpersonal influence perspective", Journal of Marketing, Vol. 54, No. 3, pp. 68-81.

Ferdinand, Augusty (2014)," Structural Equation Modeling Dalam Penelitian Manajemen: Aplikasi Model-model rumit dalam Penelitian untuk tesis S-2 dan disertasi S-3", Badan Penerbit Universitas Diponegoro, Semarang.

J.Cannon, Ch. Homburg (2001),"Buyer-Supplier Relationships and Customer Firm Costs", Journal of Marketing, 65, 1, 29-43

Kohli, Ajay K, Tasadduq Shervani, and Goutam N, Challagalla, (1998), Learning and Performance Orientation of Salespeople: The Role of Supervisor, Journal of Marketing Research, Vol. 35 (May), p.263-274.

Liljander, Verunica and Inger Roos, (2002), "Customer relationship level from spurious to true relationship", Jurnal Of Service Marketing, Special Issue On Relationship, vol 16

Marshall W. Greg, Stone H. Thomas, and Jawahar I. M, (2001). "Selection Decision Making by Sales Managers and Human Resource Manager : Decision Impact, Decision Frame, and Time of Valuation". Journal of Personal Selling and Sales Management, Vol. XXI, No. 1, p. 19-28.

Mattila, A. S., (2001), "Emotional bonding and restaurant loyalty", Cornell Hotel and Restaurant Administration Quarterly 42 (Issue 6): 73-79.

Setiawan, Andi, (2003),"Analisis Kinerja Tenaga Penjualan berdasarkan Sistem Kontrol dan Sinergi Aktivitas Tenaga Penjualan", Jurnal Sains Pemasaran Indonesia, Vol. II, No.1, p. 33-52

Shoemaker, and Mark C. Johlke (2002), "An Examination of the Antacedents of a Crucial Selling Skill : Asking Questions”, Journal of Managerial Issues, Vol XIV No.1 p. 118-131.

Spiro, R.L. and B.A. Weitz, (1990), "Adaptive Selling: Conceptualization, Measurement and Nomological Validity", Journal of Marketing Research. p. 61-69.

Sujan, Harish, Barton A. Weitz and Nirmala Kumar, (1994), "Learning Orientation, Working Smart, and Effective Selling", Journal of Marketing, Vol. 58. P. 39-52.

Verbeke, Willem J; Frank D Belschak; Arnold B Baker; Bart Dietz, (2008),"When Intelegence is (Dys) Functional for achieving Sales Performance", Journal of Marketing, p. 1-51 
Weilbaker, Dan C.(1990),"The Identification of selling needed for missionary type sales".Journal of Personal Selling and Sales Management (Summer) Vol.10, p.45-48 